\title{
Study the Prevalence of Pigeon Coccidiosis in Baghdad City
}

\author{
Elaph F. Mahdii and Haidar M. A. Al-Rubaie \\ Department of Parasitology, College of Veterinary Medicine, Baghdad University, Bagdad, Iraq \\ alath@yahoo.com \\ Accepted on 5/12/2012 \\ Summary
}

The present study was conducted to record the prevalence of pigeon coccidiosis in Baghdad city. Out of 40 birds 14 (35\%) were infected with Eimeria spp. which divided into 8 males (38.09\%) and 6 females $(31.57 \%)$. Insignificant effects on the body weight gain was recorded between the infected birds $(234.78 \pm 6.32 \mathrm{~g})$ and non infected once ( $258.461 \pm 9.2 \mathrm{~g})$; Also in both sex males $(236.87 \pm 9.41 \mathrm{~g}, 260.07 \pm 10.88 \mathrm{~g})$ and females $(232 \pm 8.63 \mathrm{~g}, 256.84 \pm 15.29 \mathrm{~g})$ respectively.

\section{Keywords: Pigeon, Coccidiosis, Prevalence, Baghdad.}

\section{Introduction}

Pigeons of the order Columbiformes are ubiquitous birds and can be found in virtually every town and city around the globe (1). The impact of parasites on birds ecology and behavior became carefully studied lately, Most of the investigations concern the relationship between parasite infection and some birds, sexual selection, sexual ornaments, breeding parameters or nestlings condition. However, papers that deal with influence of parasites on birds are still not very numerous. Mainly the interactions between birds and ectoparasites or protozoan blood parasites were studied, but the influence of other groups of endo- parasites on birds was rarely studied (2). Coccidia (Protozoa, Apicomplexa) which lived in alimentary canal, was described in various birds species. The infective stage of coccidian, oocysts, are excreted with host dropping and must be transmitted orally with food. Therefore birds foraging on the ground are specially exposed to infection (3).

Most intestinal Coccidia have a complex but direct life cycle in which the infective form of the parasite invade a single host animal for development to sexual maturity; the life cycle is complete in 1-2 weeks. Coccidia are found worldwide; Birds may be infected at any time. Although little is known about the conditions that may lead to the development of clinical disease in the wild birds, birds may become diseased more frequently during periods of stress (4). Coccidiosis of the pigeon may occasionally be seen in young squabs, especially where these are reared intensively and when conditional of hygiene are poor. Older birds serve as carrier and remain apparently healthy (5). The parasite has a form called an oocyst that is passed out in the feces; It takes 14 days in a damp and warm environment for oocyst to (ripen) to where they can develop into true coccidiosis if ingested. They can survive for long periods and are infectious as coccidiosis only when they ripen. Pigeons can be infected only by ripe oocysts of pigeon coccidia, and not by these of any other animals (6). Researchers (7) refer to the that Coccidia are common pathogenic parasites in pigeons (Columba livia). Coccidiosis is most commonly seen in young pigeons and rarely in adult birds; Infection in domesticate pigeons are typically mixed and commonly include Eimeria columborum and E. labbeana. The prevalence of infection is $5.1 \%$ to $71.9 \%$ and worldwide mortality in juvenile pigeons varies from $5 \%$ to $70 \%$ with most deaths occurring in the third and fourth month of life. The aim of the study is to estimate the prevalence of Eimeria spp in pigeons.

\section{Materials and Methods}

Fourty pigeon (males and females) of columbidae family examined during a period December 2011 to March 2012 for protozoal infections.

Two fecal analysis methods were used for examination (8). Direct smear, this methods was done by mixing a drop and tape water with bite of feces using an applicator stick on glass microscopic slide covered with slip and examined at low (10X) and high power. 
Flotation method; Comminute thoroughly a small quantity of feces, about 1 gm, with sufficient saturated salt solution in a beaker to make a fluid mixture. Pour the comminuted preparation through cheese cloth, and discard the debris. Pour fluid into straight sided tube until a convex meniscus appears at the top of the tube, and apply a cover slip immediately.

Little or no fluid should escape from the container when the cover slip is applied nor should there be so little fluid as to permit air bubbles under it. Allow prepation to stand on a level surface for 7-8 minutes, remove the cover slips apply.

Statistical evaluation was carried out by using $\mathrm{T}$ - test value less than $(\mathrm{P}<0.05)$ consider as statistically significant (9).

\section{Resullts and Discussion}

The present study shows that out of 40 pigeon $14(35 \%)$ were infected with Eimeria spp. (table, 1 and figure, 1 ).

Table, 1: Prevalence of Eimeria spp in pigeon (Columbidae).

\begin{tabular}{|c|c|c|}
\hline $\begin{array}{c}\text { Number of } \\
\text { samples } \\
\text { examined }\end{array}$ & Positive & $\begin{array}{c}\text { Percentage } \\
(\%)\end{array}$ \\
\hline $\mathbf{4 0}$ & $\mathbf{1 4}$ & $\mathbf{3 5}$ \\
\hline
\end{tabular}

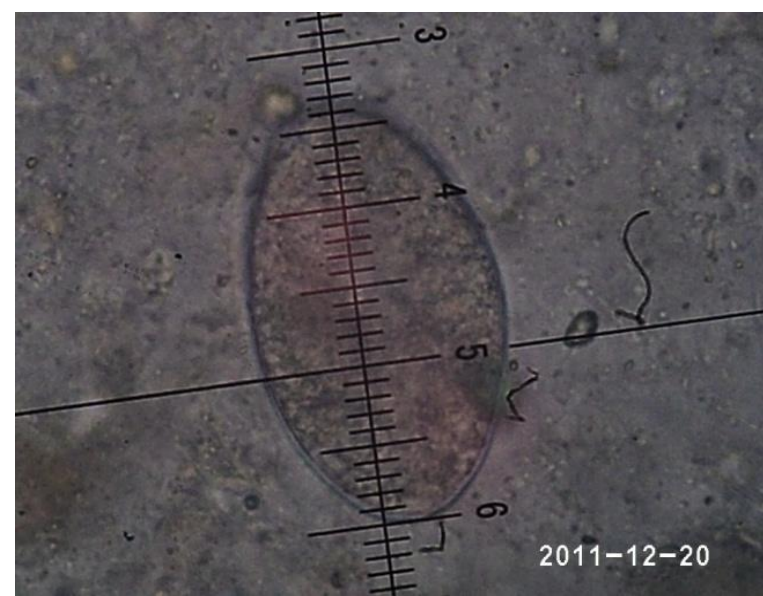

Figure, 1: Shape and diameter of Eimeria spp Oocyst in pigeon $(40 \mathrm{X})$

Infection rate according to sex: results of this study showed that the infection rate of males and females were $38.09 \%$ and $31.57 \%$ respectively (Table,2). Effect of infection on body weight: The infection with Eimeria spp. showed decrease in the body weight of infected pigeon $(234.78 \pm 6.32)$ compared with non-infected pigeon $(258.461 \pm 9.2)$. Also, In both sexes, without significant difference between infected and non-infected of both sexes (Tables, 3 and 4).

Table, 2: Prevalence of Eimeria spp infection according to sex.

\begin{tabular}{|c|cc|c|}
\hline Sex & $\begin{array}{c}\text { Number of } \\
\text { samples }\end{array}$ & Positive & $\begin{array}{c}\text { Percentage } \\
(\%)\end{array}$ \\
\hline Males & $\mathbf{2 1}$ & $\mathbf{8}$ & $\mathbf{3 8 . 0 9}$ \\
\hline Females & $\mathbf{1 9}$ & $\mathbf{6}$ & $\mathbf{3 1 . 5 7}$ \\
\hline Total & $\mathbf{4 0}$ & $\mathbf{1 4}$ & $\mathbf{3 5}$ \\
\hline
\end{tabular}

Table, 3: Effect of Eimeria spp infection on body weight of Columbidae pigeon.

\begin{tabular}{|l|l|l|}
\hline $\begin{array}{l}\text { Number of } \\
\text { samples } \\
\text { examined }\end{array}$ & $\begin{array}{l}\text { Positive } \\
\text { (Mean } \pm \text { SE) g }\end{array}$ & $\begin{array}{l}\text { Percentage }(\%) \\
\text { (Mean } \pm \text { SE) g }\end{array}$ \\
\hline $\mathbf{4 0}$ & $\mathbf{2 3 4 . 7 8} \pm \mathbf{6 . 3 2}$ & $\mathbf{2 5 8 . 4 6 1 \pm 9 . 2}$ \\
\hline
\end{tabular}

Table, 4: Effects of Eimeria spp infection in the body weight of both sex.

\begin{tabular}{|l|ll|l|} 
Sex & $\begin{array}{l}\text { Number } \\
\text { of } \\
\text { samples }\end{array}$ & $\begin{array}{l}\text { Positive } \\
(\text { mean } \pm \text { SE) } \\
\text { g }\end{array}$ & $\begin{array}{l}\text { Negative } \\
(\text { mean } \pm \text { SE) } \\
\text { g }\end{array}$ \\
\hline Males & 21 & $\begin{array}{l}236.87 \pm \\
\text { 9.41 }\end{array}$ & $\begin{array}{l}\mathbf{2 6 0 . 0 7} \pm \\
10.88\end{array}$ \\
\hline \multirow{2}{*}{ Females } & \multirow{2}{*}{19} & $\begin{array}{l}\mathbf{2 3 2} \pm \\
\mathbf{8 . 6 3}\end{array}$ & $\begin{array}{l}\mathbf{2 5 6 . 8 4} \pm \\
15.29\end{array}$ \\
\hline
\end{tabular}

Coccida are common pathogenic parasites in pigeons (Columba livia), Coccidiosis is most commonly seen in young pigeons and only rarely in adult birds; Infections in domestic pigeons are typically mixed and commonly include Eimeria columbarum and Eimeria labbeana and the reported prevalence of infection is $5.1-71.9 \%$ (7). Other researchers (10) reported infection Coccidial oocysts in $50 \%$ of the Columbia livia, while (1) was recorded on infection rate of Eimeria sp. $100 \%$. Whereas (11) found that out of 145 feed domestic pigeons (Columbia livia) 98 $(67.58 \%)$ were positive for Eimeria oocysts 80 $(55.17 \%)$ and $74(51.03 \%)$ were infected with E. columbarum and E. labbeana respectively and $56(38.62 \%)$ samples were positive for both Eimeria species. Also, the high infection rate of pigeon coccidiosis in our study may due to the stress factor that can produce an outbreak (6).

The decrease in the body weight of infected pigeons compared with non-infected one may 
be due to that the infection with coccidian parasites life cycle which is endogenous developmental cycle stages occur in the epithelial cells of the intestine from the anterior region down to the rectum and the second generation of schizonts forms may penetrate into the deeper tissues (5).

\section{References}

1. Marques, S.M.; DeQadros, R.M; Silva, C.J. and Baldo, M. (2007). Parasites of pigeons (Columba livia) in urban areas of lages Southern Brazil. Parasitol. Latinoam., 62: $183-187$.

2. Hudson, P. (1986). The effect of a parasitic nematode on the breeding production of Red Grouse. J. Anim., 55: 85 - 92.

3. Dolnik, O. (1998). Isospora coccidia (protozoa, Eimeriidae) of passerine birds on the Courish spit. Bull Scan Soc. Parasitol., 8(2): $58-68$.

4. Friend, M. and Franson, J.C. (1999). Field manual of mild life disease General field procedures and diseases of birds. USGS science for a changing world. Biological Resources Division information and Technology Report 1999. www.cmtc gor / nwhchome html.

5. Soulsby, E.J. (1968). Helminths arthropods and protozoa of domesticated animals. $6^{\text {th }} \mathrm{ed}$. Bailliere Tindall and Cassell Ltd. London, PP: $674-675$.

6. Vriends, M. Erskine, T. and Erskine, E.E. (2005). Coccidiosis In: Barron completes pet owner's manuals. Barron s Educatl. Series, P: 96.

7. Krontwald Junghanns, M.E; Zebisch, R. and Schynidt, V. (2009). Prevalence and treatment of coccidiosis in domestic pigeons (Columba livia, forma domestica) with
Coccidia invasions are able to cause negative changes in hosts, intestine flora, and reduce the amount of the vitamins from group B in hosts' organism (12) or have not found any effects on adult birds (3 and 13). These results agree with our results.

particular emphasis on to ltrazuril. J. Avian Med. Surg., 23(1): 1-5.

8. Coles, E.H. (1974). Veterinary Clinical Pathology. $2^{\text {nd }}$ Ed. W.B. Sanders Company Philadelphia P: 474.

9. المحمد ، نعيم ثناني احمد و الراوي ، خاشع محمود و يونس ، مؤيد احمد و المر اني ، الحئ وليد خضير (1986). مبادئ الاحصاء. دار الكتب للطباعة و النشر . جامعة الموصل .

10. Adlard, R.D.; Peirce, M.A. and Lederer, L. (2004). Blood parasite of birds from southeast Queens land. Ornithology, 104: $191-196$

11. GǘL, A.; ÖZdal, N.; Deĝer, S. and Denizhan, V. (2009). Prevalence of coccidia and helminth species in domestic pigeons (Columba livia domestica) in Van. Yúzứncố yil úniversitesi Veteriner Fakúltesi. Dergisi., 20(2): $45-48$.

12. Kruszewicz, A.G. (1995). The occurence of isoporolacazei (Coccidia : Eimeriidae) and its influence on nestling growth in House sparrows (passer domesticus) and Tree sparrows (posrer montanus) In: Nestling mortality of granivorous birds due to microorganisms and toxic substances : synthesis Pinowski, J. et al (eds) PWN Warsaw, PP: $291-305$.

13. Bonczar, P. A.; Pospiech, N. and Rosciszewska, M. (1998). Urban pigeon coccidia infection. Wiad. Parazytol., 44:430 $-439$.

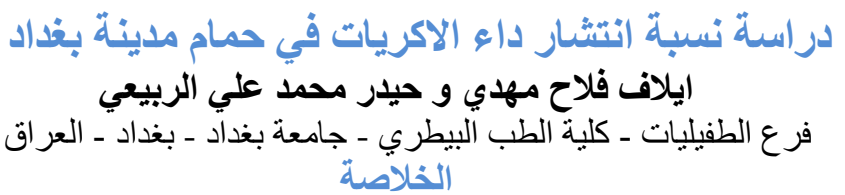

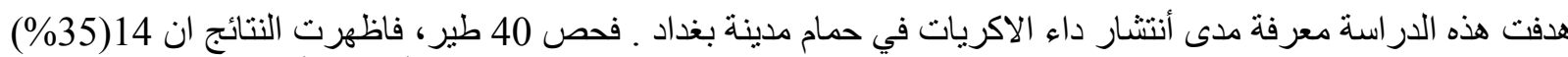

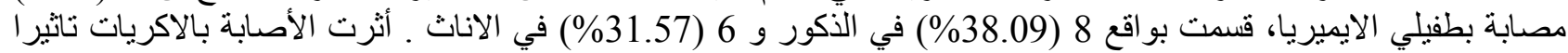

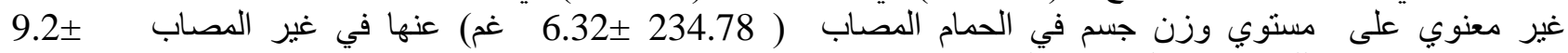

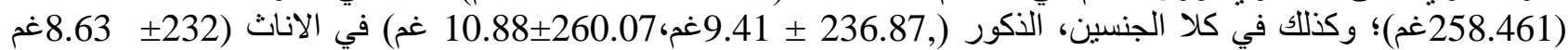

